\title{
UNDERSTANDING OF DIALECTICS IN THE MODERN EDUCATIONAL PROCESS
}

\author{
Michael Chernikov' ${ }^{1}$, Larisa Perevozchikova ${ }^{2}$, Evgeniia Avdeenko $^{3}$, Ksenia \\ Nazarenko ${ }^{4}$
}

\author{
${ }^{1}$ Doctor of Philosophy, Assistant Professor, Voronezh State Technical University, 20 years of \\ October street, 84, Voronezh, Russia, E-mail: mv.chernikov@gmail.com \\ ${ }^{2}$ Doctor of Philosophy, Professor, Voronezh State Technical University, 20 years of October street, \\ 84, Voronezh, Russia, E-mail: perevozch@vgasu.vrn.ru \\ ${ }^{3}$ Candidate of Philosophical Sciences, Voronezh State Technical University, 20 years of October \\ street, 84, Voronezh, Russia, E-mail: jjaane@yandex.ru \\ ${ }^{4}$ Candidate of Philosophical Sciences, Voronezh State Technical University, 20 years of October \\ street, 84, Voronezh, Russia, E-mail: petrenkoksenia@vgasu.vrn.ru
}

\begin{abstract}
This article examines the issue of the legitimacy of the methodological use in the modern system of higher education of the ontological interpretation of dialectics, according to which dialectics can be positioned as a general theory of development. The historical and philosophical reasons that led to the ontologization of dialectics and the further use of dialectics as a general theory of development in the cognitive and educational processes are considered. The position is carried out and substantiated according to which the understanding of dialectics as a general theory of development is outdated and does not stand up to criticism from the standpoint of modern scientific knowledge.
\end{abstract}

Keywords: modern education, methodology, theory of dialectics, dialectics as a general theory of development.

\section{INTRODUCTION}

In the modern Russian system of higher education, which took over from the system of higher education that developed in the USSR, the doctrine of dialectics plays a very significant role, which is assigned the role of a key methodological principle of understanding development processes in nature, society and human thinking.

However, the question of the justification of the widely and constantly carried out application of the methodological principle of dialectics in the system of modern education is becoming more acute and, accordingly, more and more urgent.

The understanding of dialectics as a general theory of development goes back to Hegel's philosophy and was consolidated in the works of K. Marx and F. Engels, who for the Soviet system of higher education acted as an indisputable authority and could not be subjected to critical analysis. However, in post-Soviet Russia, a critical examination of Marxist doctrine has become both possible and valid. In the process of such critical analysis, a number of fundamental conceptual provisions of Marxist theory were questioned, including the understanding of dialectics as a general theory of development.

This article attempts to answer the extremely relevant question for the methodological equipment of the modern system of higher education: how legitimate is the understanding of dialectics as a general theory of development? 


\section{METHODOLOGY}

The article uses the following research methods for the question posed: conceptual analysis of texts, the method of conceptual comparative studies, the method of cause-and-effect and logical implication.

\section{DISCUSSION}

The issue of the explanatory and prognostic potential of dialectics was discussed by a fairly large number of authors who, as a rule, had a Marxist orientation. In the Soviet Union, such authors should, first of all, include: L.M. Deborin [Deborin 1929], M.A. Lifshits [Lifshits 2004], E.V. Ilyenkova [llyenkov 2019-2020], Z. M. Orudzhev [Orudzhev 1973], V.A. Vazyulin [Vazyulin 1978]. At the same time, a positive assessment of the heuristic and methodological potential of dialectical theory prevailed in the Soviet Union, which was quite natural under the conditions of a harsh ideological dictate. It is impossible, at the same time, not to notice that the main emphasis in the application of dialectics was transferred to the area of thinking and the theory of the development of society, and not to the area of understanding the natural processes of development. Although to argue with the fundamental (and which seems to be extremely outdated from the standpoint of modern science) F. Engels' work "Dialectics of Nature" [Engels 1953], few dared.

In post-Soviet Russia, we observe both a continuation of a positive assessment in understanding the heuristic and methodological potential of dialectics, and an entire large deontologization of dialectics, the removal of the scope of dialectics beyond the analysis of natural processes. As a modern Russian philosopher writes about this: "Generally speaking, the ontologization of dialectics is one of the most important vices of" Soviet "Marxism ...

The consequence of this ontologization is an extremely abstract, dogmatic understanding of dialectics as a science of laws operating in the same schematic form in nature, society and thinking. "The opposite of the 'dialectic' understanding of dialectics is that it is not represented everywhere in the same way. She looks different everywhere. And in its concrete and at the same time universal form, it can be presented only as a dialectic of thinking, as a dialectic of the development of human cognition, that is, as logic and a theory of cognition.

As for history and nature, its application here presupposes historical science and natural science: and dialectics is not applied here to the subject of these sciences, but to the sciences themselves - to history and natural science. " [Mareev 2008. S. 24.]

However, as in the USSR, the main dialectical studies were carried out within the subject area of spirit, not nature. But it was not particularly accepted to argue with the understanding of dialectics as a general theory of development based on the teachings of Hegel, and then of Marx and Engels.

It seems that the time has come to fundamentally approach the question of the legitimacy of understanding dialectics as a general theory of development. This is how the question is posed in this article. Let's move on to the corresponding conceptual analysis.

\section{RESULTS}

I must say that although the history of dialectics is of ancient origin and begins in the framework of ancient philosophy, the status of a General theory of development dialectic receives only from Hegel and from Marx takes over the use of the conceptual apparatus of the dialectic and, in particular, Hegel formulated the three basic laws of dialectics: the law of unity and struggle of opposites (i.e., a dialectical contradiction) which determines (at least claims to be) a source of development of any integrated system; the law of the transition of quantitative changes into qualitative ones, as well as the nature of the development of any integral system and the law of negation of negation (the so-called dialectical removal), which determines (at least claims to be) the direction of development of any integral system.

It is difficult to say why Marx (and Engels), while carrying out a deep revision of the king of philosophy of those years - Hegel and criticizing his system of objective idealism from a materialistic standpoint, did not produce a corresponding critical reflection in relation to the main method of Hegel's philosophy, namely, dialectics. After all, it would be quite reasonable to assume that the inversion of Hegel's philosophy should also affect the validity of using the main method of philosophy in fundamentally new conditions, when not matter is derived from consciousness (Hegel), but consciousness is derived from matter (Marx)? Dialectics as a general theory of development became an indisputable principle and methodological imperative both in the framework of Soviet science and in the framework of the Soviet higher education system.

but today it is impossible not to notice that dialectics as a general theory of development is practically not 
used in modern science. The modern conceptual apparatus both in the field of human and social sciences (economics, sociology, psychology, etc.) and (especially) in the field of natural sciences (physics, chemistry, biology, etc.) "does not know" dialectics and does not turn to the "dialectical method" for solving scientific problems. and this situation, which demonstrates the lack of demand for dialectics in the framework of modern science, is far from accidental.

It can be argued that the ontologization of dialectics produced by Hegel and, in fact, preserved by Marx, is simply incorrect from a scientific point of view. Let us examine this statement on the example of the basic law of dialectics - the law of dialectical negation (unity and struggle of opposites).

According to this law, dialectical contradiction (the unity and struggle of opposites) is the main and decisive source of development for any system. But such a view is essentially anthropomorphic! Contradiction is a logical category that represents the situation of the presence of two statements (speeches) describing one situation (referent) from opposite positions. A description of an objectively existing situation is only considered correct when it is consistent. This is not an ontological requirement, but an epistemological one. Even if the description is not a static situation, but a dynamic process (which is usually emphasized by apologists of dialectics), the requirement of consistency in the description of objectively existing reality still acts as a methodological imperative. That is why the detection of contradictions in conceptual constructions is an indicator of their incompleteness and - in this sense-serves as a source of development of the corresponding conceptual system.

This is exactly how Hegel used the principle of dialectical contradiction. Thesis - antithesis (first negation) dialectical "subtraction" (second negation) - this is the way of developing a concept that describes a certain reality, but not this very reality! It is another matter that for Hegel, reality is a derivative of rationality. Since the primary and fundamental in Hegel's philosophy is the Absolute Spirit, whose conceptual work (Absolute Idea) is embodied in nature, society, and, finally, in human thinking, the logic of the development of the concept (Absolute Idea) becomes at the same time the logic of development of the objective Absolute ideas, namely society and human thinking (Hegel has no development of nature).

However, Marx, passing from the position of objective idealism to the position of materialism (turning Hegel's philosophy "upside down") and eliminating (as pure speculation) the Absolute Spirit loses (available to Hegel) the right to project the logic of the development of a concept onto the logic of the development of objective reality. Rebelling against Hegel's system of objective idealism, in which the epistemological is ontologized and built into its own ontology as primary and independent of any epistemology, Marx can no longer (and should not!) Use the conceptual tools of epistemology for ontological purposes. The materialist cannot (at least, without a serious preliminary justification) apply the first law of dialectics, since the contradiction (not in the concept describing reality, but in the very) objective reality, at best, is a "metaphor", but, in essence, is simply mythologeme. Accordingly, we have to admit that the entire theory of dialectics, built on the basis of illegal ontologization, which claims to be a general theory of development, is essentially mythological, and from a scientific point of view, incorrect.

\section{CONCLUSION}

The article substantiates the position according to which the concept of dialectics as a general theory of development, playing the role of a pivotal methodological principle in the system of modern education, is outdated and does not stand up to criticism from the standpoint of the modern level of development of science. Understanding of this circumstance calls into question the validity of using a methodological arsenal in the system of higher education, which includes ontologically interpreted dialectics. It seems advisable to carry out the appropriate correction of the methodological equipment of the modern higher education system.

\section{REFERENCE LIST}

Ershov B. A., Semenkova E. V. (2016) The consequences of the collapse of the Soviet Union. International Journal of Humanities and Natural Sciences. № 3. Pp. 20-22. (in Russ).

Ershov B.A. (2010) The Russian Orthodox Church and secular power in the Voronezh province in the XIX early XX centuries. GOU VPO "Voronezh State Technical University". Voronezh. 167 p.

Ershov B.A. (2010) The system of spiritual education in Voronezh province in the 19th century. Education and Society. №. 5 (64). Pp. 105-108. 
Ershov B.A., Fursov V.N. (2018) The Russian Church in the State Mechanism of Russia. Bulletin SocialEconomic and Humanitarian Research. № 1. Pp. 32-37.

Ershov B.A., Perevozchikova L.S., Romanova E.V. (2019) Globalization and Intensification of Spiritual Values in Russia in the Philosophical Aspect. 6th International Conference on Education and Social Sciences Abstracts \& Proceedings. Pp. 208-212.

Ershov B.A., Volkova E.A., Frolova E.V., Volkov N.M., Pletnev V.I. (2019) The Revolution of 1905-1907. in Russia: results and consequences. 6th International Conference on Education and Social Sciences. Abstracts \& Proceedings. Pp. 213-220. (in Engl).

Romanova E.V., Perevozchikova L.S., Ershov B.A. (2017) The Lifestyle of the Human Being in the Information Society. 3rd International Conference on Advances in Education and Social Sciences Proceedings of ADVED Pp. 950-954.

Adorno T. (1999) Izbrannoe: sotsiologiya muzyki. M. SPb. (in Russ).

Adorno T. (2003). Negative dialectics. M. (in Russ).

Althusser, L. (2006). For Marx. M. Praxis. (in Russ).

Benjamin V. (1996). A work of art in the era of its technical reproducibility. M. (in Russ).

Vazulin, V. A. (1978). Dialectics of the historical process and methodology of its research. M. Publishing House "Knowledge". (in Russ).

Gramsci, A. (1959). Selected Works In Three Volumes. Prison Notebooks. M. (In Russ).

Deborin I. M. (1929). Dialectics And natural science. M. (In Russ).

llyenkov E.V. (2019-2020). Collected works in 3 volumes, Moscow: Canon+ ROOI "Rehabilitation". (in Russ).

Lefor K. (2000). Political essays. M. (in Russ).

Lifshitz Mich. (2004). What is a classic? M. (in Russ).

Lukács G. (2003). History and class consciousness. Studies in Marxist Dialectics. M: "Logos-Altera". (in Russ).

Mareev S.N. (2008). From the history of Soviet philosophy: Lukacs-Vygotsky-llyenkov. M.: Cultural Revolution. (in Russ).

Marcuse G. (2000). Reason and revolution. M. (in Russ).

Materialistic dialectics as a general theory of development. In 4 volumes (1982-1983). M. Science. (in Russ).

Orujev Z. (1973). Dialectics as a System. Politizdat. (in Russ).

Sartre J.P. (2008). Method problems. M. Academic Project. (in Russ).

Horkheimer M, Adorno T. (1997). Dialectics of Enlightenment: Philosophical fragments. Moscow. St. Petersburg (in Russ).

Engels, F. (1953). Dialectics of Nature. M. (in Russ).

Marcuse H. (1958). Soviet Marxism: A Critical Analysis. New York: Columbia University Press. Pp. 25-28. 